\title{
Analisis Performa Deteksi Objek Bergerak pada Algoritma Background Subtraction dan Algoritma Frame Difference
}

\author{
Dewi Anggraini Puspa Hapsari ${ }^{1}$, Widya Khafa Nofa ${ }^{2}$, Sugeng Santoso ${ }^{3}$ \\ ${ }^{1}$ Program Studi Manajemen Universitas Gunadarma, ${ }^{2}$ Program Studi Sistem Informasi Universitas \\ Gunadarma, ${ }^{3}$ Program Studi Teknik Informatika Universitas Raharja \\ E-mail: ${ }^{1}$ dewi.anggraini.puspa@gmail.com, ${ }^{2}$ widyakhafa@gmail.com, ${ }^{3}$ sugeng.santoso@ raharja.info
}

\begin{abstract}
Abstrak
Penelitian ini bertujuan untuk membandingkan performa dari dua buah algoritma deteksi objek, yaitu algoritma background subtraction dan algoritma frame difference. Performa yang dibandingkan dari kedua algoritma ini adalah hasil akurasi deteksi objek dan waktu pemrosesan. Data diambil dari hasil akuisisi video kamera pengawasan. Langkah penelitian diawali dengan melakukan akuisisi video kemudian memecah menjadi frame sequential dan selanjutnya dilakukan deteksi objek pergerakan kamera. Hasil dari deteksi objek berupa sebuah foreground mask untuk masing-masing frame sequential. Dari analisis pengujian didapatkan untuk performa berdasarkan akurasi deteksi objek dan waktu pemrosesan dari dataset yang diambil menunjukkan jika algoritma frame difference lebih unggul dibandingkan algoritma background subtraction.
\end{abstract}

Kata Kunci-Deteksi Objek Bergerak, Algoritma Background Subtraction, Algoritma Frame Difference

\begin{abstract}
This study compares the performance of two object detection algorithms, namely the background subtraction algorithm and the frame difference algorithm. They reached the interpretation of these two algorithms due to object detection accuracy and processing time. The data is taken from the acquisition of video surveillance cameras. The research step begins with video acquisition, breaks it into sequential frames, and detects camera movement objects. The result of object detection is a foreground mask for each sequential frame. The test analysis obtained for performance based on object detection accuracy and processing time from the dataset taken shows that the frame difference algorithm is superior to the background subtraction algorithm.
\end{abstract}

Keywords - Object detection, Background Subtraction Algorithm, Frame Difference Algorithm

\section{Pendahuluan}

Sistem pengawasan (video surveillance system) mengidentifikasi area yang menarik dalam scene pada video, yaitu entitas yang bergerak melalui scene [1]. Berdasarkan KBBI, bergerak adalah peralihan tempat atau kedudukan, baik hanya sekali maupun berkali-kali. Jadi objek bergerak adalah objek yang berpindah dari tempat atau kedudukan atau tidak diam saja. Sedangkan didalam video, bergerak dapat didefinisikan sebagai perubahan nilai intensitas citra dimana obyek yang diam adalah latar atau background dari suatu frame pada video dan obyek bergerak adalah foreground [2].

Deteksi objek bergerak (motion detection) merupakan bagian penting dari sistem pengawasan, karena sistem selanjutnya menganalisis kegiatan dari benda bergerak tersebut. Kegiatan yang dianalisis akan mengklasifikasikan apakah objek bergerak tersebut adalah kendaraan, orang atau sekelompok orang.

Deteksi objek memungkinkan kamera pengawasan untuk melacak cuplikan scene dari lokasi tertentu. Metode ini secara akurat mengenali dan menempatkan beberapa contoh objek tertentu dalam sebuah video. Saat objek bergerak melalui scene tertentu atau melintasi frame tertentu, sistem menyimpan informasi. 
Deteksi objek bergerak merupakan proses untuk dilakukan pemisahan antara frame background dan frame foreground. Pemisahan ini dilakukan untuk menghasilkan foreground mask. Foreground mask yang dihasilkan dijadikan tahap awal untuk melakukan pemrosesan video digital.

Beberapa penelitian telah dilakukan dalam deteksi pergerakan objek dan mengimplementasikan ke dalam algoritma deteksi yang berbeda. Algoritma yang umumnya digunakan adalah algoritma background subtraction [3] dan algoritma frame difference [4]. Algoritma background subtraction menggunakan teknik pengurangan (selisih) antara frame sekarang $\left(\mathrm{f}_{\mathrm{i}}\right)$ dengan frame background-nya [5]. Sedangkan algoritma frame difference menggunakan teknik pengurangan (selisih) antara frame sekarang $\left(\mathrm{f}_{\mathrm{i}}\right)$ dengan frame sebelumnya $\left(\mathrm{f}_{\mathrm{i}-1}\right)[6]$.

Performa dari sebuah algoritma ditentukan dari akurasi deteksi objek dan waktu pemrosesan. Hasil dari perbandingan performa ini digunakan sebagai acuan untuk menerapkan algoritma deteksi objek pada dataset.

Berdasarkan uraian tersebut maka penelitian ini bertujuan untuk menganalisis performa perbandingan algoritma deteksi objek yang bergerak pada algoritma background subtraction dengan algoritma frame difference. Adapun performa yang akan dianalisis adalah hasil akurasi deteksi objek dan waktu pemrosesan algoritma tersebut yang diimplementasikan pada hasil akuisisi video surveillance system.

\section{Metode Penelitian}

Metode yang digunakan pada penelitian ini terdiri dari 3 (tiga) tahapan, yaitu:

1. Studi literatur. Tujuan dari tahap ini adalah mendapatkan pijakan dan/atau fondasi untuk memperoleh landasan teori, kerangka berfikir dan alat penelitian yang akan digunakan untuk melakukan analisis perbandingan dari algoritma deteksi objek bergerak. Sumber dari literatur yang digunakan adalah jurnal, artikel ilmiah dan modul atau referensi lain yang terpercaya.

2. Desain dari algoritma. Tahap ini merupakan tahap desain dari algoritma deteksi objek bergerak yang dikembangkan menggunakan metode SDLC (Software Development Life Cycle) dengan model Waterfall yaitu: analisa, rancangan, pengkodean, dan implementasi. Penerapan metode SDLC dilakukan pada kedua algoritma.

3. Implementasi. Tahap ini dengan menggunakan perangkat lunak (software) MATLAB akan mengimplementasikan hasil desain dari algoritma yang telah dibuat. Selanjutnya dilakukan analisis pengujian hasil dari implementasi.

Berdasarkan dari studi pustaka dengan topik deteksi objek bergerak, algoritma background subtraction dan algoritma frame difference maka terbentuklah alur tahap penelitian untuk penelitian ini yang digambarkan pada Gambar 1.

Tahap penelitian diawali dengan melakukan akuisisi video. Akuisisi video bertujuan untuk mengumpulkan data video yang didapatkan dengan mencapture dengan menggunakan kamera pengawasan. Dalam melakukan proses akuisisi video, ada beberapa faktor yang perlu menjadi perhatian utama dalam prosesnya. Faktor tersebut adalah jenis alat akuisisi, resolusi kamera dan, teknik pencahayaan, teknik zooming (perbesar dan perkecil kamera) dan sudut pengambilan data [7].

Dataset yang dihasilkan dari akuisisi video, selanjutnya akan dipecah terlebih dahulu menjadi frame sequential. Setiap frame yang dihasilkan hanya akan diambil komponen RGB saja dikarenakan komponen RGB memuat informasi dari dataset.

Setiap frame dengan komponen RGB akan diterapkan dua buah algoritma deteksi objek bergerak, yaitu algoritma background subtraction dan algoritma frame difference. Penerapan masingmasing algoritma pada frame sequential akan dilakukan di evaluasi. Evaluasi dilakukan dengan melihat pada dari hasil akurasi pendeteksian dan waktu pemrosesan algoritma saat diimplementasikan pada perangkat lunak MATLAB. Tahap akhir dari proses ini adalah melakukan analisis perbandingan dari hasil kedua algoritma tersebut. 


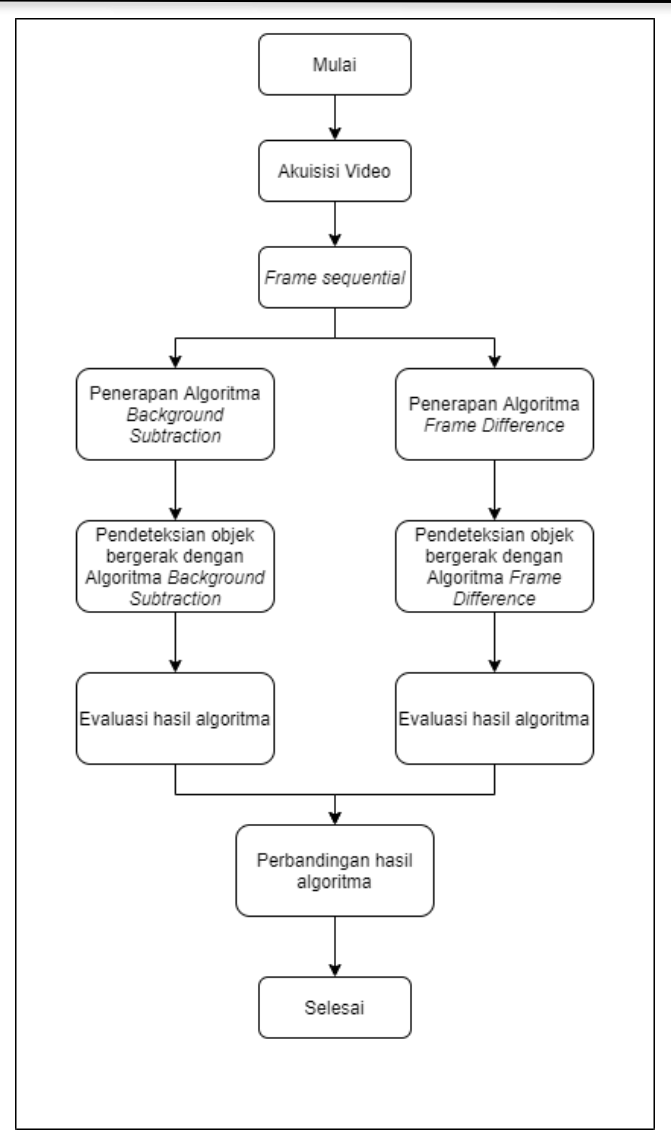

Gambar 1. Alur tahap penelitian

Algoritma background subtraction menggunakan teknik pengurangan (selisih) antara frame sekarang $\left(\mathrm{f}_{\mathrm{i}}\right)$ dengan frame background-nya [5]. Frame background diambil dari frame awal pada data video. Frame ini yang akan disimpan terlebih dahulu untuk dijadikan pembanding untuk setiap frame selanjutnya $\left(\mathrm{f}_{\mathrm{i}}\right)$. Foreground mask dihasilkan setelah proses pengurangan dilakukan proses thresholding, dimana selisih frame yang diambil jika hasil selisih lebih besar dari thresholding level. Proses pengurangan dilakukan dengan mengurangi dengan frame background hingga frame habis. Gambar 2 merupakan gambar yang mengilustrasikan algoritma background subtraction.

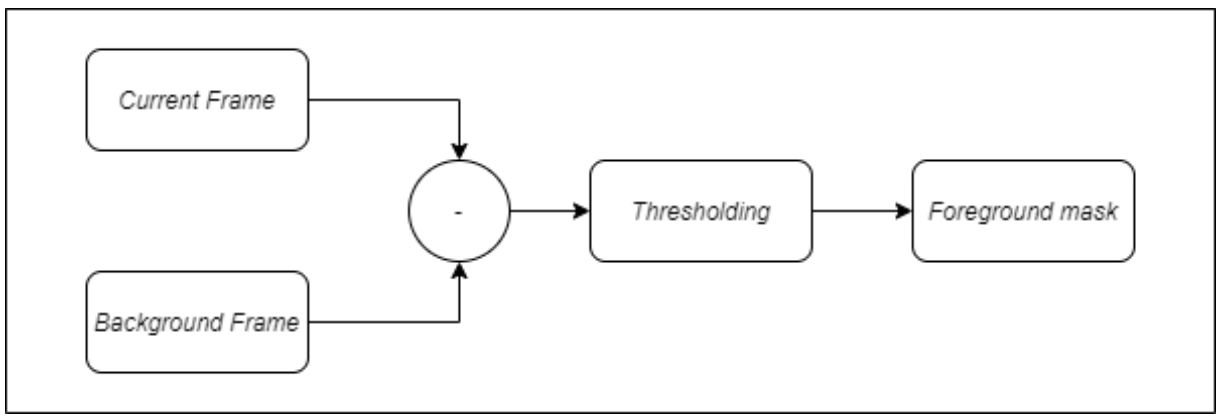

Gambar 2. Algoritma background subtraction

Algoritma frame difference menggunakan teknik pengurangan (selisih) antara frame sekarang (fi) dengan frame sebelumnya (fi-1) [6]. Pada algoritma ini, selisih tidak dilakukan pada frame latar (background) melainkan pada frame sebelumnya sehingga tidak ada pendefinisian untuk frame awal. 


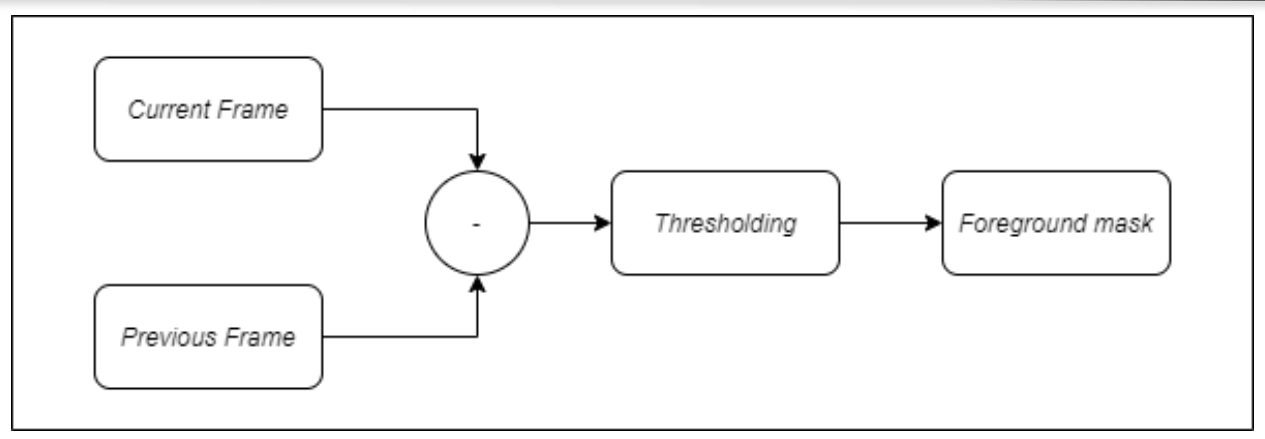

Gambar 3. Algoritma frame difference

\section{Hasil dan Pembahasan}

\subsection{Akuisisi Video}

Akuisisi video merupakan proses atau kegiatan untuk melakukan pengambilan data video yang akan digunakan pada penelitian ini. Data video diambil dengan menggunakan kamera fix outdoor yang diletakkan didalam ruangan.

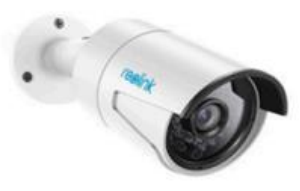

Gambar 4. Contoh kamera fix indoor-outdoor

Spesifikasi kamera yang digunakan seperti pada Tabel 1.

Tabel 1. Spesifikasi kamera yang digunakan

\begin{tabular}{|l|l|}
\hline & \multicolumn{1}{|c|}{ Kamera } \\
\hline Jenis & Kamera fix outdoor \\
\hline Resolusi Kamera & $2 \mathrm{MP}$ \\
\hline Ukuran Citra & $640 \times 480$ \\
\hline Frame rate & $25 \mathrm{fps}$ \\
\hline
\end{tabular}

Ketinggian kamera diletakkan setinggi 2 meter dari permukaan tanah. Ketinggian ini disesuaikan untuk mendapatkan viewfinder yang cukup luas. Pengambilan data dilakukan pada malam hari sehingga membutuhkan bantuan cahaya buatan (lighting). Tata letak kamera seperti terlihat pada Gambar 5.

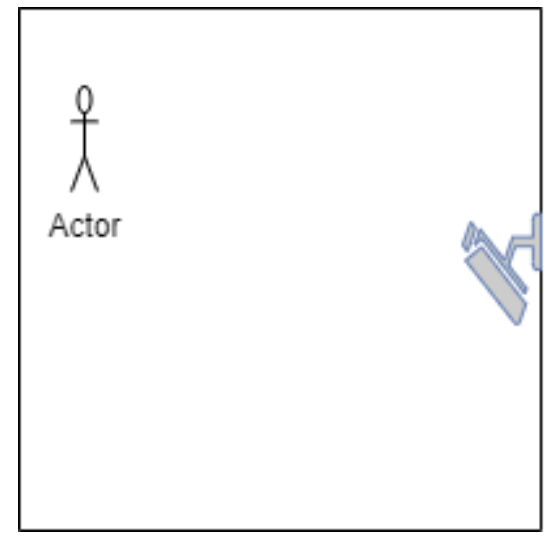

Gambar 4. Tata letak pengambilan data 
Objek yang digunakan dalam penelitian ini adalah manusia yang bergerak. Kegiatan pergerakan yang dilakukan adalah dengan berdiri, jalan, duduk dan berbaring. Kegiatan ini dilakukan secara berkesinambungan selama berdurasi 6 detik.

Spesifikasi perangkat keras (hardware) dan perangkat lunak (software) yang digunakan untuk melakukan implementasi dan pengujian tertuang pada Tabel 2.

Tabel 2. Spesifikasi perangkat keras (hardware) dan perangkat lunak (software) yang digunakan

\begin{tabular}{|c|l|c|}
\hline \multicolumn{1}{|c|}{$\begin{array}{c}\text { Perangkat keras } \\
\text { (hardware) }\end{array}$} & $\begin{array}{c}\text { Perangkat lunak } \\
\text { (software) }\end{array}$ \\
\hline Processor & $\begin{array}{l}\text { Intel(R) Core(TM) i7- } \\
\text { Memory } \\
11800 \mathrm{H}\end{array}$ & \\
\hline VGA & $16.0 \mathrm{~GB}$ & \\
\hline
\end{tabular}

\subsection{Pemisahan frame}

Data video hasil akuisisi akan dipecah menjadi frame yang berdiri sendiri. Proses pemisahan diawali dengan membaca data video. Dari data video tersebut, dilakukan proses pre-processing yang merupakan proses untuk membaca informasi dari data video, yaitu panjang (length) frame. Setiap frame akan diambil komponen R, G dan B untuk diterapkan kedua algoritma. Gambar 4 menunjukkan alur proses pemisahan frame pada data video.

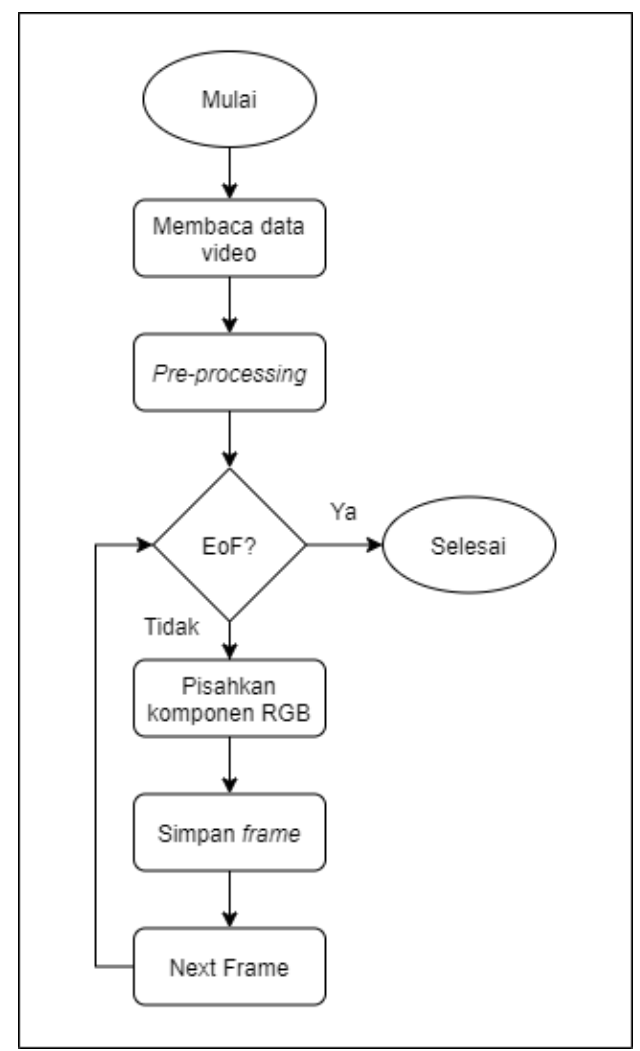

Gambar 4. Alur proses pemisahan frame

Gambar 5 menunjukkan frame background dari dataset. Frame background didapatkan pada awal frame diakarenakan kamera yang digunakan tidak bergerak atau static. Frame background ini menjadi frame latar dari video. 


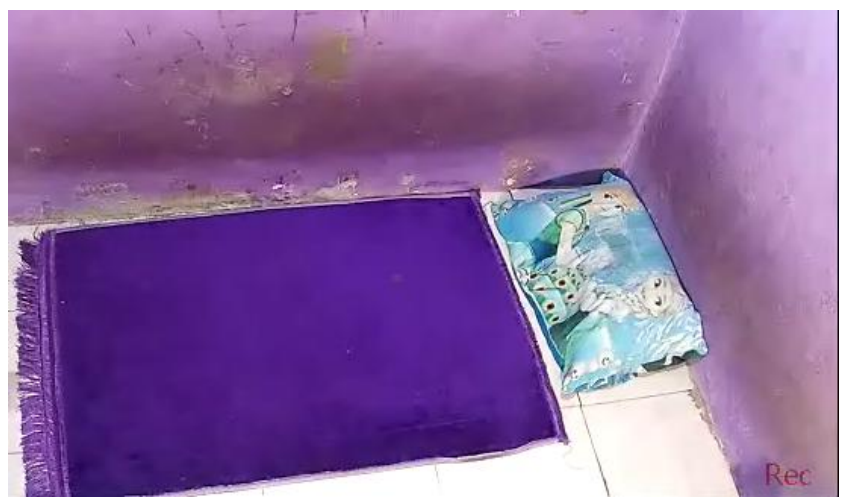

Gambar 5. Frame background dari dataset

Hasil pemisahan frame pada dataset adalah 120 frame. Setiap frame akan disimpan dalam format citra bmp. Contoh hasil pemisahan frame yang berhasil dilakukan terlihat pada Tabel 3.

Tabel 3. Contoh hasil pemisahan frame

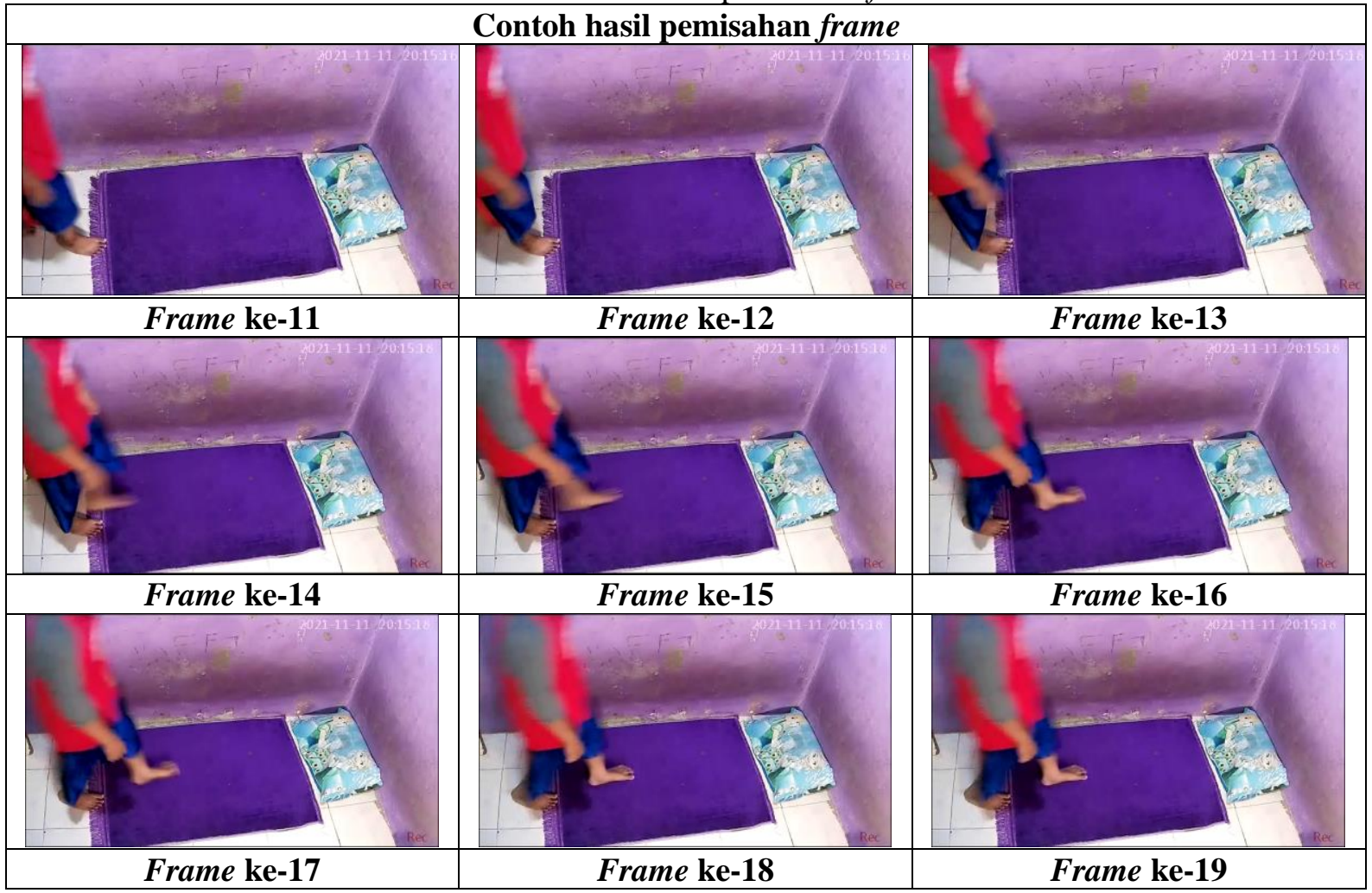

\subsection{Algoritma Background Subtraction}

Frame dari data yang sudah dipecah akan diterapkan dengan algoritma background subtraction. Berdasarkan pada Gambar 2 yang menunjukkan langkah penerapan algoritma background subtraction, maka proses pertama adalah dengan membaca frame pertama sebagai frame background. Semua frame tersebut dirubah terlebih dahulu menjadi citra grey-scale. Selanjutnya dilakukan proses pembacaan frame berikutnya dimana frame tersebut akan dilakukan proses pengurangan (subtraction) dengan frame 
background. Hasil pengurangan akan dilakukan pengecekan thresholding yang digunakan sebagai batas dari frame tersebut. Proses ini akan dilakukan hingga frame terakhir.

Contoh hasil dari penerapan algoritma background subtraction yang menghasilkan foreground mask diilustrasikan pada Tabel 4. Penerapan algoritma background subtraction dilakukan untuk 120 frame dari data video. Thresholding level dari data ini adalah 0.113725490196078.

Berdasarkan Tabel 4, terlihat jika algoritma background subtraction berhasil diterapkan hingga menghasilkan foreground mask untuk setiap frame yang telah dipisahkan. Akurasi penerapan algoritma masih kurang baik dikarenakan terdapat noise yang ditangkap oleh algoritma sebagai foreground mask. Waktu pemrosesan untuk implementasi algoritma ini adalah 1.888894 detik.

Tabel 4. Contoh foreground mask hasil algoritma background subtraction

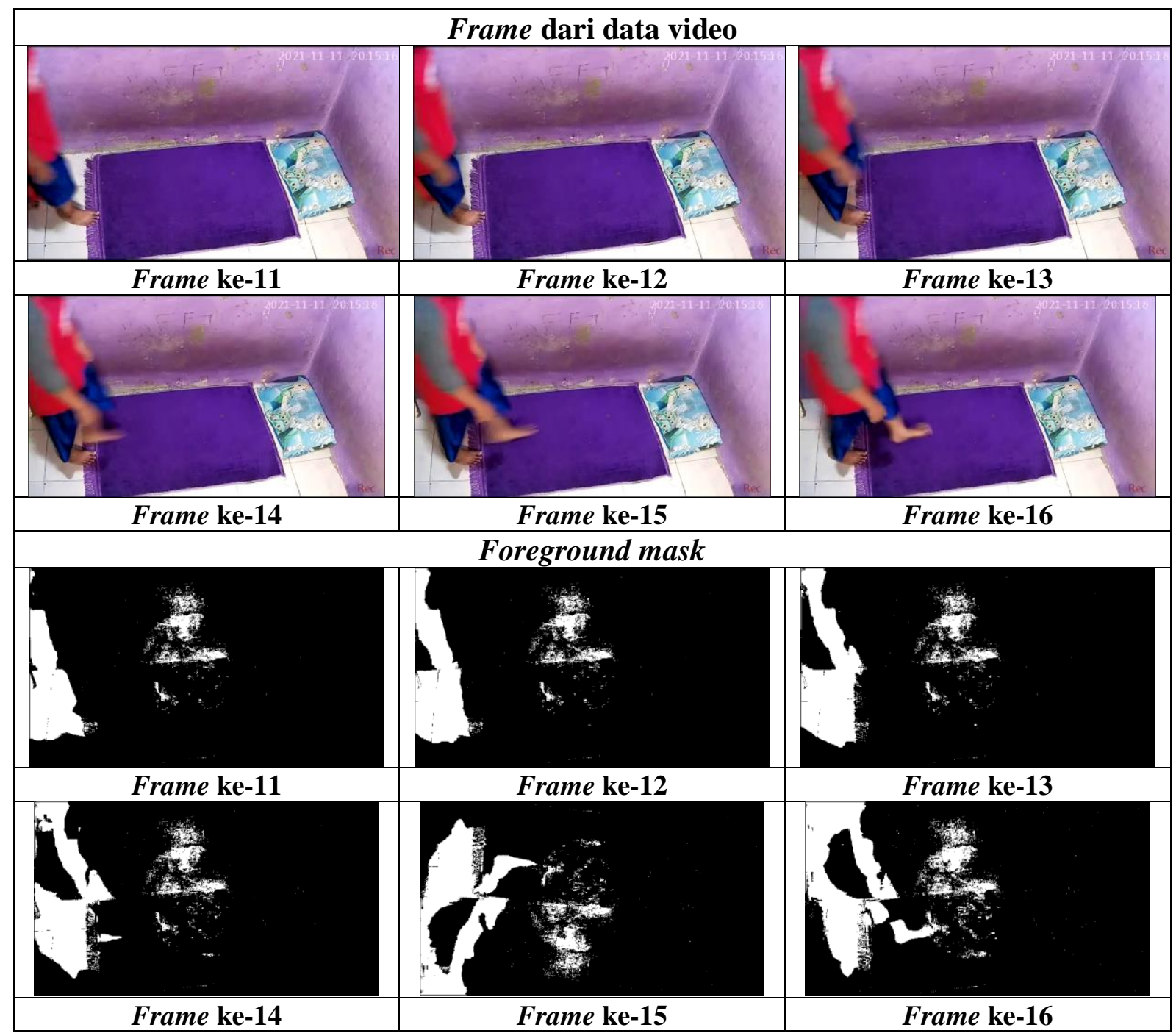

\subsection{Algoritma Frame Difference}

Seperti halnya pada algoritma background subtraction, pada algoritma frame difference pun diterapkan setelah proses pemisahan frame. Berdasarkan Gambar 3 yang menunjukkan proses penerapan algoritma frame difference maka langkah awal adalah dengan membandingkan frame pertama dengan frame selanjutnya. Kemudian menghitung selisih dari kedua frame tersebut. Selisih 
ISSN : $2356-5195$

Online ISSN: 2654 - 8704

tersebut akan akan membentuk foreground mask menyesuaikan dengan thresholding level yang dibentuk 0.027450980392157 .

Tabel 5. Contoh foreground mask hasil algoritma frame difference

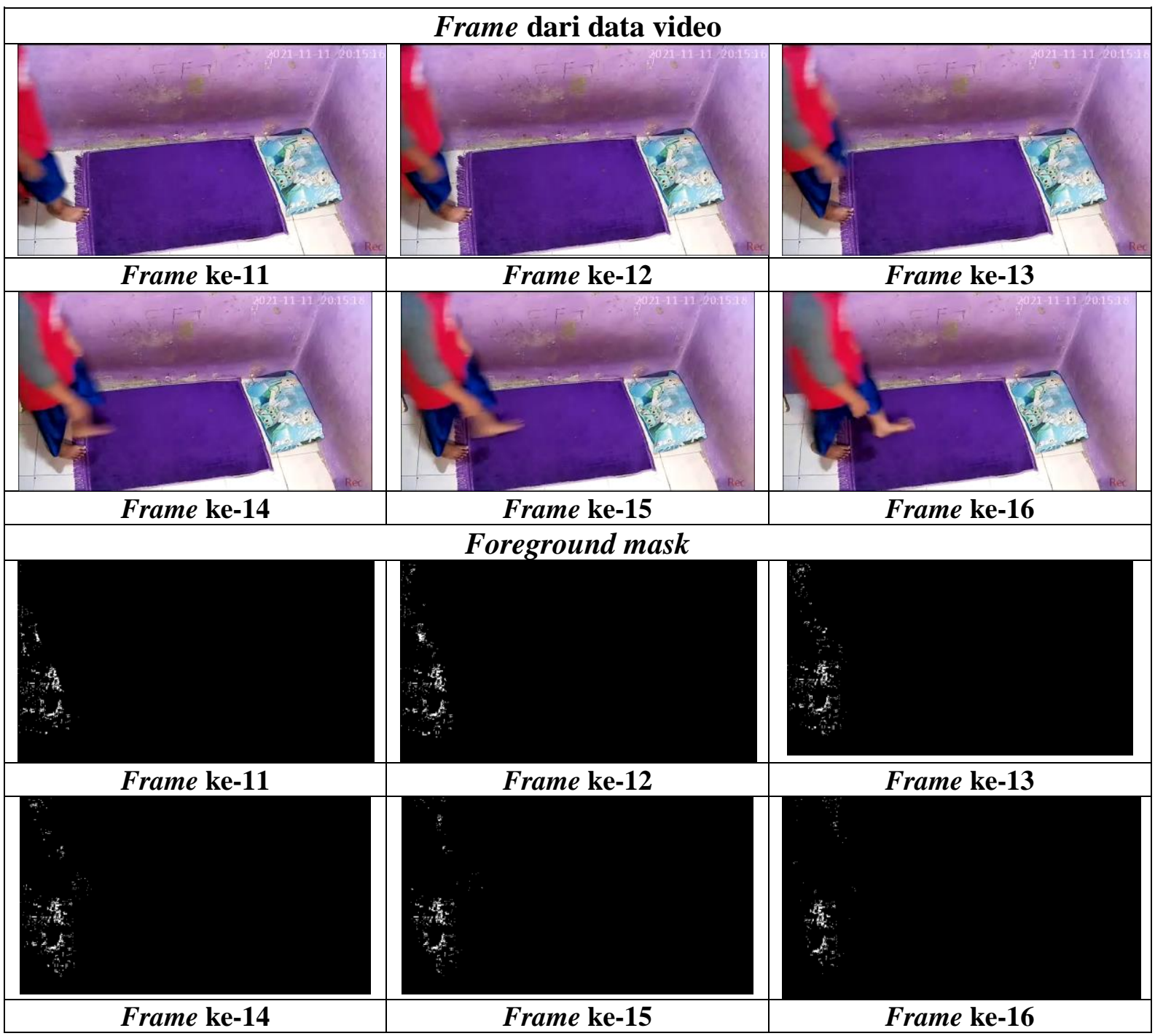

Berdasarkan Tabel 5, terlihat jika algoritma frame difference berhasil diterapkan hingga menghasilkan foreground mask. Foreground mask yang dihasilkan tepat mengikuti pada pergerakan objek. Tidak terdapat noise pada hasil foreground mask. Waktu pemrosesan untuk implementasi algoritma adalah 0.799775 detik.

\subsection{Analisis Pengujian}

Penerapan deteksi objek dengan menggunakan algoritma background subtraction dan algoritma frame difference berhasil dilakukan dan menghasilkan foreground mask seperti tertuang pada Tabel 4 dan Tabel 5. Tabel analisis pengujian antara kedua algoritma dengan melihat dari akurasi pendeteksian objek dan waktu pemrosesan tertuang pada Tabel 6. 
Tabel 6. Analisis Pengujian

\begin{tabular}{|l|l|l|}
\hline & \multicolumn{1}{|c|}{$\begin{array}{c}\text { Algoritma } \\
\text { Background Subtraction }\end{array}$} & \multicolumn{1}{c|}{$\begin{array}{c}\text { Algoritma } \\
\text { Frame Difference }\end{array}$} \\
\hline $\begin{array}{l}\text { Deteksi objek } \\
\text { bergerak }\end{array}$ & $\checkmark \begin{array}{l}\text { Akurasi deteksi objek kurang } \\
\text { baik. } \\
\text { Berhasil mendeteksi semua } \\
\text { objek tetapi terdapat noise yang } \\
\text { dianggap sebagai foreground } \\
\text { mask. }\end{array}$ & $\begin{array}{l}\checkmark \\
\checkmark \text { Akurasi deteksi objek baik. } \\
\text { Berhasil mendeteksi semua } \\
\text { objek dan tidak terdapat noise. }\end{array}$ \\
\hline Thresholding level & 0.113725490196078 & 0.027450980392157 \\
\hline $\begin{array}{l}\text { Waktu } \\
\text { pemrosesan }\end{array}$ & 1.888894 detik & 0.799775 detik. \\
\hline
\end{tabular}

\section{Kesimpulan}

Deteksi objek bergerak untuk menghasilkan foreground mask merupakan langkah awal dalam pemrosesan data video. Foreground mask digunakan untuk memisahkan area background dan foreground. Kedua algoritma yang digunakan berhasi diterapkan dan menghasilkan foreground mask.

Berdasarkan Tabel 6, performa algoritma frame diference lebih baik dibandingkan dengan performa dari algoritma background subtraction. Pada algoritma background subtraction masih terdapat noise yang dianggap sebagai foreground mask. Waktu pemrosesan yang diperlukan oleh algoritma frame difference dalam mengolah data video dengan jumlah 120 frame lebih cepat jika dibandingkan dengan algoritma background subtraction.

\section{Saran}

- Objek yang diteliti pada penelitian ini adalah satu orang objek yang bergerak sehingga dapat dimungkinkan jika melakukan dengan dataset menggunakan lebih dari satu objek atau kerumunan (crowl).

- Pada algoritma background subtraction masih terdapat noise yang ditangkap oleh algoritma sebagai foreground mask sehingga masih perlu ditambahkan filter untuk melakukan proses menghilangkan noise tersebut.

- Perbandingan performa berdasarkan hasil akurasi pendeteksian objek dan waktu pemrosesan, dimungkinkan untuk membandingkan kompleksitas dari algoritma.

\section{Daftar Pustaka}

[1] L. A. Mushawwir and I. Supriana, "Deteksi dan Tracking Objek untuk Sistem Pengawasan Citra Bergerak," Konf. Nas. Inform. 2015 Deteksi, vol. 2354-645X/, no. October, pp. 1-10, 2015.

[2] P. Hartoto, J. T. Elektro, I. Teknologi, and S. Nopember, "Sistem Deteksi Kecepatan Kendaraan Bermotor pada Real Time Traffic Information System."

[3] W. Supriyatin, Y. Rafsyam, and Jonifan, "Analisis Pelacakan Objek Menggunakan Background Estimation Pada Kamera Diam Dan Bergerak," Orbith Maj. Ilm. Pengemb. Rekayasa dan Sos., vol. 13, no. 2, pp. 124-130, 2017.

[4] R. Muhamad, T. Yulianti, S. R. Sulistiyanti, S. Purwiyanti, and F. X. A. Setyawan, "Deteksi Objek Bergerak Pada Video Bawah Air Menggunakan Metode Frame Differencing," $J$. EECCIS, vol. 13, no. 2, pp. 100-104, 2019.

[5] A. I. Iskandar, "Analisis Objek Bergerak Dengan Metode Background Subtraction," Celeb. 
ISSN : $2356-5195$

Online ISSN: 2654 - 8704

Eng. J., vol. 1, no. April, pp. 41-53, 2019.

[6] S. Saluky, "Moving Object Detection on CCTV Surveillance Using the Frame Difference Method," ITEJ (Information Technol. Eng. Journals), vol. 4, no. 2, pp. 114-122, 2019, doi: 10.24235/itej.v4i2.52.

[7] E. Tjin, Kamera DSLR Itu Mudah! Bukune, 2011. 